\title{
Comparison of natural Mozzarella cheese with acid casein based Mozzarella cheese analogue
}

\author{
Chetan Dharaiya ${ }^{1}$, Atanu Jana ${ }^{2}$, Amit Patel ${ }^{3}$ and Dhinal Patel ${ }^{4}$
}

Received: 12 June 2021 / Accepted: 25 June 2021 / Published online: 07 September 2021

(C) Indian Dairy Association (India) 2021

\begin{abstract}
Attempts were made in the present investigation to prepare a mozzarella cheese analogue using acid casein as protein source and partially hydrogenated palm kernel oil as fat source. Though the analogue was formulated to match with natural Mozzarella cheese for proximate composition, it significantly differed from natural cheese for ash, salt, calcium and $\mathrm{pH}$. There was significant difference in textural, functional and sensory properties between natural Mozzarella cheese and its analogue. Natural cheese had higher hardness, cohesiveness, springiness, gumminess and chewiness while had lower adhesiveness. Analogue possessed better shredability but required more time for melting in oven at $230^{\circ} \mathrm{C}$ compared to natural cheese. The natural cheese had higher meltability, stretchability and fat leakage. Natural cheese outplayed analogue in terms of sensory characteristics particularly for appearance, flavor, melting and stringiness while analogue was less chewy than natural cheese. Both the samples were at par in terms of microbiological analysis. Overall, natural Mozzarella cheese was much better than analogue in all aspects studied.
\end{abstract}

Keywords: Analogue, , Functional characteristics Mozzarella cheese, Proximate composition, Textural characteristics, Sensory characteristics

\footnotetext{
${ }^{1,3,4}$ Dairy Technology Department, SMC College of Dairy Science, Anand, India

${ }^{2}$ Department of Dairy Processing and Operations, SMC College of Dairy Science, Anand, India

Chetan Dharaiya $(\square)$

Dairy Technology Department, SMC College of Dairy Science, Anand, India

Email: chetandharaiya@gmail.com; Mobile No.: +91 7573013697
}

\section{Introduction}

Mozzarella cheese is a proud member of pasta-filata family of cheeses. It is characterized by plasticizing and kneading of the fresh curd in hot water, which imparts a typical fibrous structure as well as unique melting and stretching properties to the final product. The demand of Mozzarella cheese is increased with increasing popularity of pizza throughout the world as well as in India (Sabikhi et al. 2015; Jana and Tagalpallewar, 2017).

Mozzarella cheese analogue is similar to Mozzarella cheese for compositional, textural, functional and sensory characteristics, and are prepared by partial or complete replacement of milk fat by vegetable fat and/or milk protein by vegetable protein (Hennelly et al. 2005; Noronha et al. 2008; Cunha et al. 2010; Arimi et al. 2012). Cheese analogues are being manufactured commercially in developed country since long but manufacturing process has been patented. Cheese analogues were developed because consumers wanted healthy product having low calorie, low cholesterol and preferably containing polyunsaturated fats and fortified with essential vitamins and minerals. Manufacture of 'tailor-made' cheese analogues can have all these nutritional traits, over and above the functional property they expect from such cheese. (Badem and Ucar, 2016).

Jana and Upadhyay (2001) standardized a method for preparation of Mozzarella cheese analogue using acid casein and vegetable oil blended with hydrogenated vegetable fat as the protein and fat sources respectively while Shah et al. (2010) prepared analogue using rennet casein and plastic cream. Sodium caseinate and calcium caseinate are other preferable sources of casein for preparation of Mozzarella cheese analogues (Sherkat and Walker, 2002; Guinee et al. 2004; Mizuno and Lucey, 2005).

A cheese analogue is intended to have similar characteristics as that of natural cheese but matching with its natural counterpart is a great challenge because consumers expect similar sensory characteristics in analogues as that of natural cheese. Therefore, in the present investigation, Mozzarella cheese analogue was prepared using acid casein as a protein source as well as specialty palm kernel oil as a fat source and compared with milk based 
Mozzarella cheese for its compositional, textural, functional and sensory characteristics as well as microbiological quality.

\section{Materials and Methods}

Acid casein and rennet casein, containing $87.12 \%$ and $81.24 \%$ protein respectively, were obtained from M/s. Mahaan Protein Ltd., Kosikalan, India. Specialty palm kernel oil (partially hydrogenated) based vegetable fat (Melting point $-32^{\circ} \mathrm{C}$ ) was obtained from M/s. Kamani Oil Industries Pvt. Ltd., Mumbai, India. Calcium chloride, dihydrate; di-sodium hydrogen orthophosphate, dehydrate; tri-sodium citrate, dihydrate; anhydrous citric acid; lactic acid and lecithin were procured from M/s. Loba Chemie Pvt. Ltd., Mumbai, India. Pre-gelatinized starch (Pregenil XT) was obtained from M/s. Madhu Hydrocolloids Pvt. Ltd., Ahmedabad, India. Natural Mozzarella cheese flavouring paste was supplied by M/s. Adare Food Ingredients Pvt. Ltd., Vitthal Udyognagar, India. Vacuum-evaporated salt (Tata brand) and fresh pre-baked pizza loaves were obtained from a local market. Rennet (Maxiren brand) was supplied by DSM Food Specialities Ltd., Mumbai, India.

\section{Preparation of Mozzarella cheese analogue}

Mozzarella cheese analogue (MCA) was prepared as per the method described by Dharaiya et al. (2019) with minor modifications. The formulation of MCA is shown in Table 1 and the method of manufacture is described hereunder.

Acid casein, common salt, pre-gelatinized starch, cheese flavouring and calcium chloride were added to hot $\left(80^{\circ} \mathrm{C}\right)$ potable water containing emulsifying salts. After part acidification with lactic acid solution (1:10 w/v of water), vegetable fat (@15\%) in melted condition $\left(40^{\circ} \mathrm{C}\right)$ was added to the casein based dough and subsequently acidified to desired $\mathrm{pH}$ using the same lactic acid solution. The final dough formed was heated to $80^{\circ} \mathrm{C}$ for 3 $\mathrm{min}$, shaped in ball form, allowed to cool to ambient temperature and vacuum packed in polyethylene bags ( $85 \mu$ thickness) followed by refrigerated $\left(7 \pm 1^{\circ} \mathrm{C}\right)$ storage. A Hobart food processor (M/s. Hobart Corp. Canada - Model No. N 50), operating at three different speeds, was used to blend the ingredients to form dough.

\section{Preparation of natural Mozzarella cheese}

Natural Mozzarella cheese was prepared using the method standardized by Chavhan et al. (2015) with minor modifications. The process is described hereunder in brief:

Standardized $($ Casein/Fat $=0.70 \pm 0.01)$ fresh buffalo milk was pasteurized at $72^{\circ} \mathrm{C} / 16 \mathrm{~s}$ and cooled to $15^{\circ} \mathrm{C}$ followed by acidification up to $\mathrm{pH} 5.2-5.25$ (Acidity: 0.45 to $0.5 \%$ lactic acid) using $20 \% \mathrm{w} / \mathrm{v}$ lactic acid solution. Rennet was added at the rate of $1.5 \mathrm{~g} / 100 \mathrm{~L}$ and temperature was raised to $27^{\circ} \mathrm{C}$ and allowed the curd to set. Curd was cut in to $1 \mathrm{~cm}^{3}$ cube and cooked along with whey. Temperature was raised to $37^{\circ} \mathrm{C}$ in $30 \mathrm{~min}$. Whey was drained when the acidity of $0.40-0.42 \%$ LA was achieved. Common salt was added at the rate of $2.5 \%(\mathrm{w} / \mathrm{w})$ of the quantity of curd (approximately $110 \mathrm{~g}$ curd is obtained from $1 \mathrm{~kg}$ of milk) followed by plasticizing using hot water at $90-95^{\circ} \mathrm{C}$ and moulding in ball form. The cheese balls were immersed in pasteurized chilled water maintained at $4^{\circ} \mathrm{C}$ for $2 \mathrm{~h}$. Water was drained and Mozzarella cheese balls were vacuum packed in polyethylene bags $(85 \mu$ thickness) and stored at $7 \pm 1^{\circ} \mathrm{C}$.

\section{Chemical analysis}

The Mozzarella cheese analogues, natural Mozzarella cheese, acid casein and rennet casein were analysed for moisture, fat, protein (by semi-micro Kjeldahl method) and ash using the method prescribed by FSSA (2015). The analogues and natural Mozzarella cheese were analysed for salt (Kosikowski, 1982), calcium (Kindstedt and Kosikowski, 1985) and pH (Patel et al. 1986).

\section{Texture profile analysis}

Texture of the experimental cheese samples, i.e. analogue and natural Mozzarella cheeses, was analysed using M/s. Lloyd Instrument (Model 1000, Lloyd Ltd., LRX, England; Sr. No. 160374) with 5 Kilo Newton (KN) load cell at cross-head speed of $20 \mathrm{~mm} /$ $\min$. The cheese samples were diced to $1 \mathrm{~cm}^{3}$ size followed by tempering to $23 \pm 1{ }^{\circ} \mathrm{C}$ and were subjected to $70 \%$ compression ratio. The results were recorded using Nexygen 2.0 software. Hardness, cohesiveness, springiness and adhesiveness were directly measured from the graph while gumminess and chewiness were calculated from their force-distance compression curve. Average of five samples for each treatment was considered.

\section{Functional characteristics}

Analogue and natural cheese samples were evaluated subjectively for shredability. Several criteria were considered for shredability such as ease of shredding, length and thickness of shreds and the behaviour of shreds after shredding. A stainless steel shredder with pore size diameter of $3 \mathrm{~mm}$ was used for shredding. Meltability of experimental samples was checked using Schrieber test (Park et al. 1984) while stretchability was examined using Fork test (USDA, 2012) and fat leakage was analysed using a test developed by McMahon et al. (1996).

\section{Sensory evaluation of cheese as a pizza topping}

The experimental cheese samples were examined for pizza making by conducting baking trials using a freshly prepared pizza base with $15 \mathrm{~cm}$ diameter and $15 \mathrm{~mm}$ thickness. One week old cheese sample (75 g) was shredded and used immediately for topping the pizza base. Vegetable filling was intentionally avoided for appropriate examination of sensory quality of cheese. Higher quantity of cheese samples, i.e. $75 \mathrm{~g}$, was used for better evaluation only. The shredded cheese samples with pizza base were baked in oven at $230^{\circ} \mathrm{C}$ till complete melting of cheese. It 
took 4 to $8 \mathrm{~min}$. for complete melting depending on type of cheese. The pizzas were served to trained judges for sensory evaluation in hot condition at more than $65^{\circ} \mathrm{C}$ temperature.

A 9-point hedonic scale was used for evaluation of sensory attributes such as appearance (considering colour, melting, fat leakage and browning), flavour, melting, stringiness and chewiness. Final scoring was carried out by a total score of 50 (Table 5).

\section{Microbiological analysis}

The experimental cheese samples were analyzed for the standard plate count (SPC), Coliform count and Yeast and Mold count (Y\&M) as per the methods described by FSSA (2012).

\section{Statistical analysis}

In each part of the study, data obtained from 4 independent trials were statistically analyzed using completely randomized design. Statistical analysis was carried out using one-way ANOVA(Steel and Torrie, 1980).

\section{Results and Discussion}

\section{Proximate composition of analogue and natural Mozzarella cheese}

The chemical composition of cheese analogues greatly influences its textural and functional characteristics (Bachmann, 2001). The moisture, fat, protein, moisture in fat free substances (MFFS), fat on dry matter (FDM) and protein at constant moisture (PCM) of acid casein based mozzarella cheese analogue and natural mozzarella cheese are statistically at par while a significant difference $(\mathrm{P}<0.05)$ has been observed for ash, common salt and calcium content as well as $\mathrm{pH}$ (Table 2). The analogue was formulated to have similar chemical composition as that of natural
Table 1 Formulation of Mozzarella cheese analogue

\begin{tabular}{lc}
\hline Ingredients & Rate of addition, \% \\
\hline Vegetable fat & 15.00 \\
Acid casein & 21.30 \\
Tri-sodium citrate & 0.90 \\
Disodium hydrogen phosphate & 1.60 \\
Lecithin & 0.15 \\
Citric acid & 0.18 \\
Calcium chloride & 0.30 \\
Pre-gelatinized starch & 2.00 \\
Cheese flavouring & 3.00 \\
Common salt & 1.00 \\
Water & 54.57 \\
\hline
\end{tabular}

Mozzarella cheese. The significantly higher ash content in analogue could be attributed to the addition of various emulsifying salts, common salt, pre-gelatinized starch, calcium chloride and flavouring substances in the formulation. Natural Mozzarella cheese prepared by direct acidification resulted in partial demineralization yielding lower ash content in final product (Dave et al. 2003). The significantly lower salt content in natural cheese could be due to partial loss of salt in hot water during plasticizing process (Jana and Upadhyay, 2001). The significantly lower calcium content in acid casein based Mozzarella cheese analogue could be ascribed to loss of calcium while preparation of acid casein in whey (Dave et al. 2003). The calcium content of analogue was lower than natural cheese even after external addition of calcium chloride. The $\mathrm{pH}$ of analogue was kept significantly higher as desired functional property such as stretch in case of Mozzarella cheese was obtained at higher $\mathrm{pH}$ in analogue which could be due to alkaline nature and buffering action of emulsifying salts added during the preparation of analogue (Kindstedt et al. 2004). Jana and Upadhyay (2001) also prepared Mozzarella cheese analogue using acid casein and obtained similar results.

Textural properties of analogue and natural Mozzarella cheese

Table 2 Proximate composition of analogue and natural Mozzarella cheese

\begin{tabular}{llll}
\hline Parameters & $\begin{array}{l}\text { Mozzarella Cheese } \\
\text { Analogue }\end{array}$ & $\begin{array}{l}\text { Natural Mozzarella } \\
\text { Cheese }\end{array}$ & $\mathrm{CD}(0.05)$ \\
\hline Moisture & $53.22 \pm 1.44$ & $53.65 \pm 2.05$ & $\mathrm{NS}$ \\
Fat & $17.50 \pm 0.48$ & $17.25 \pm 0.24$ & $\mathrm{NS}$ \\
Protein & $23.29 \pm 0.29$ & $23.52 \pm 0.30$ & $\mathrm{NS}$ \\
MFFS $^{1}$ & $64.31 \pm 1.12$ & $64.83 \pm 1.52$ & $\mathrm{NS}$ \\
FDM $^{2}$ & $37.40 \pm 0.23$ & $37.22 \pm 0.23$ & $\mathrm{NS}$ \\
Protein $\left(51 \%\right.$ moisture $^{3}$ & $24.30 \pm 0.32$ & $24.74 \pm 0.34$ & $\mathrm{NS}$ \\
Ash & $3.78 \pm 1.06^{\mathrm{b}}$ & $2.66 \pm 0.86^{\mathrm{a}}$ & 0.18 \\
Salt & $1.13 \pm 0.11^{\mathrm{b}}$ & $0.93 \pm 0.18^{\mathrm{a}}$ & 0.13 \\
Calcium & $0.36 \pm 0.08^{\mathrm{a}}$ & $0.50 \pm 0.06^{\mathrm{c}}$ & 0.08 \\
pH & $5.89 \pm 0.12^{\mathrm{a}}$ & $5.43 \pm 0.04^{\mathrm{b}}$ & 0.14 \\
\hline
\end{tabular}

*All the values are in per cent except for $\mathrm{pH}$; 1 - Moisture in fat-free substances; 2 - Fat on dry matter; 3 - Protein at constant moisture. Values shown with differing superscripted alphabets in the same row differs significantly (P d" 0.05$)$ from each other. 
Texture is an important indicator for evaluating the quality and functional characteristics of cheese (Monaco et al. 2008). The analogue and natural cheese differed significantly $(\mathrm{P}<0.05)$ for hardness, springiness, adhesiveness, gumminess and chewiness while they were statistically similar in terms of cohesiveness. The natural cheese had higher hardness which could be due to presence of milk fat which has higher melting point $\left(29\right.$ to $\left.45^{\circ} \mathrm{C}\right)$ compared to partially hydrogenated vegetable fat $\left(32^{\circ} \mathrm{C}\right)$ used in preparation of analogue as well as difference in fat crystallization behavior. Crystallization of milk fat is a complex phenomenon due to fatty acid composition and glyceride structure as well as formation of mixed crystals and different polymorphs (Rachana and Surendranath, 2021) while in case of palm kernel oil, lower melting triglycerides are in liquid form even at refrigeration temperature (Dang et al. 2015). Furthermore, the natural cheese contained stronger casein network while casein powder used in the preparation of analogue hardly had time for hydration during preparation, forming less dense casein network (Jana and Upadhyay, 2001).

The difference in the cohesiveness and springiness of analogue and natural cheese might be the result of difference in protein structure, state of protein hydration and $\mathrm{pH}$ (Monaco et al. 2008). The addition of pre-gelatinized starch in the formulation of analogue might have resulted in weakened casein-casein interaction which might have led to reduced cohesiveness of analogue (Shah et al. 2010).

The higher values for springiness in natural cheese than that of analogue could be due to the better protein hydration in natural cheese. Acid casein is dehydrated product and proper hydration for the manufacture of good quality analogue is highly essential (Ennis and Mulvihill, 1999). Springiness also depends on the degree of adsorption of protein on fat surface which depends on the level of saturated fatty acids present in fat. Higher the saturated fatty acids, better the adsorption of protein on fat surface and ultimately higher springiness (Lobato-Calleros et al. 1997).

The analogue displayed significantly $(\mathrm{P}<0.05)$ higher adhesiveness which may be due addition of partially hydrogenated vegetable oil. Incorporation of hydrogenated oil in cheese analogue resulted in less cohesive, less elastic and more adhesive product (Hennelly et al. 2005). Addition of emulsifying salt also has notable impact on adhesiveness of the cheese analogue. Because of compact, globular structure and low molecular weight, native milk protein does not show good adhesiveness. Addition of emulsifying salts results in decreased calcium crosslinks, leading to higher adhesiveness (Savello et al. 1989).

Gumminess is product of hardness and cohesiveness while chewiness is product of gumminess and springiness. Natural cheese had higher hardness, cohesiveness and springiness which resulted in higher gumminess and chewiness also compared to analogue.

\section{Functional characteristics of analogue and natural Mozzarella cheese}

The flavor of Mozzarella cheese analogue is not appreciable due to absence of milk fat as well as lack of fermentation but the enduse of Mozzarella cheese analogue is as a pizza topping, hence, functional characteristics are more significant. It is difficult to separate natural cheese from its analogue due to use of other ingredients in pizza. Functional characteristics, such as browning, melting, fat leakage and stretching, of cheese and its analogue have significant role in consumers' perception about quality of cheese (Rowney et al. 1999). Functional characteristics were analyzed after one week as one week ageing is suggested in case of natural cheese to get better baking properties (Guinee, 2002).

Shredability: Shredability is one of the important characteristics of Mozzarella cheese as shredding is essential for application as pizza topping. Several criteria were evaluated to analyze shredability, viz. ease of machinability, the shape and integrity of cheese shreds, the tendency of shreds to mat and tendency to produce fines during shredding.

Shredability of analogue is rated slightly better than that of natural cheese. Analogue easily produced thick and long shreds while natural cheese produced thick and short shreds with slight difficulty as well as the shreds were moist and had tendency to mat after shredding. Hence, the shredability of analogue was rated very good while that of natural cheese was rated good.

Table 3 Textural characteristics of analogue and natural Mozzarella cheeses

\begin{tabular}{llll}
\hline Parameters & $\begin{array}{l}\text { Mozzarella Cheese } \\
\text { Analogue }\end{array}$ & $\begin{array}{l}\text { Natural Mozzarella } \\
\text { Cheese }\end{array}$ & CD $(0.05)$ \\
\hline Hardness, N & $15.54 \pm 0.74^{\mathrm{a}}$ & $18.04 \pm 1.21^{\mathrm{b}}$ & 1.18 \\
Cohesiveness & $0.302 \pm 0.04^{\mathrm{a}}$ & $0.411 \pm 0.05^{\mathrm{b}}$ & 0.08 \\
Springiness, mm & $3.58 \pm 0.17^{\mathrm{a}}$ & $5.07 \pm 0.19^{\mathrm{b}}$ & 0.68 \\
Adhesiveness, N-mm & $0.29 \pm 0.04^{\mathrm{a}}$ & $0.18 \pm 0.02^{\mathrm{b}}$ & 0.09 \\
Gumminess, N & $5.31 \pm 0.12^{\mathrm{a}}$ & $7.05 \pm 0.09^{\mathrm{b}}$ & 0.23 \\
Chewiness, N-mm & $19.03 \pm 1.26^{\mathrm{a}}$ & $35.76 \pm 2.09^{\mathrm{b}}$ & 3.86 \\
\hline
\end{tabular}

* Values shown with differing superscripted alphabets in the same row differs significantly $(\mathrm{P} \leq 0.05)$ from each other. 
The analogue displayed better shredability than natural cheese which could be due to the difference in orientation of fat and protein molecules in analogue. The casein curd gets fused together due to heat processing and the presence of emulsifying salt during the preparation of analogue while in case of natural cheese the fusion takes place during plasticizing process. The higher ash content of analogue also helps in better shredability (Childs et al. 2007). The non-matting characteristics of analogue could be ascribed to presence of pre-gelatinized starch in the formulation of analogue (Shah et al. 2010).

Meltability: Melting quality of cheese is related to its ability to melt to uniform, smooth and homogeneous consistency without releasing oil and becoming watery. Individual cheese shred should not be visible upon melting (Johnson, 2000).

Melting time in oven at $230^{\circ} \mathrm{C}$ was statistically $(\mathrm{P}<0.05)$ higher for analogue than natural cheese. Melting quality of natural cheese was found superior to that of analogue which could be ascribed to orientation of fat, protein and moisture molecules in analogues. Natural cheese had shown better fusion which could be attributed to moist surface and better cohesiveness among cheese shreds (Kindstedt et al. 2004). Jana and Upadhyay (2001) found superior meltability for analogue which could be ascribed to different manufacturing process for natural cheese while Guinee et al. (2000) reported better meltability for low-moisture partly skimmed Mozzarella cheese than analogue.

Fat leakage: Free-oil formation is the propensity of the liquid fat to separate from melted cheese and accrue in pockets or pools, particularly at the cheese surface (Dharaiya et al. 2019). An optimum free-oil formation is considered desirable in Mozzarella cheese to obtain shiny appearance, preventing dehydration of cheese mass and browning on the surface of cheese (Jana and Mandal, 2011).

The lower fat leakage in case of analogue could be attributed to incorporation of emulsifying salts in the formulation (Shah et al. 2010). Processed Mozzarella cheese containing 0.5-1.5\% trisodium citrate as an emulsifying salt displayed lower fat leakage than control sample prepared without emulsifying salt (Rizvi et al. 1999) while Jana and Upadhyay (2001) found no significant difference in analogue and natural cheese samples. Table 4 Functional characteristics of analogue and natural Mozzarella cheese

\begin{tabular}{llll}
\hline Parameters & $\begin{array}{l}\text { Mozzarella Cheese } \\
\text { Analogue }\end{array}$ & $\begin{array}{l}\text { Natural Mozzarella } \\
\text { Cheese }\end{array}$ & CD $(0.05)$ \\
\hline Shredability & Very Good & Good & - \\
Meting time in oven at $230^{\circ} \mathrm{C}, \mathrm{s}$ & $457.50 \pm 9.13^{\mathrm{a}}$ & $425.00 \pm 8.05^{\mathrm{b}}$ & 12.76 \\
Meltability, arbitrary value & $2.41 \pm 0.21^{\mathrm{a}}$ & $3.49 \pm 0.36^{\mathrm{b}}$ & 0.65 \\
Fat leakage, $\mathrm{cm}^{2}$ & $2.56 \pm 0.18^{\mathrm{a}}$ & $3.89 \pm 0.18^{\mathrm{b}}$ & 0.61 \\
Fork stretch, cm & $15.50 \pm 1.35^{\mathrm{a}}$ & $21.50 \pm 1.49^{\mathrm{b}}$ & 2.05 \\
\hline
\end{tabular}

* Values shown with differing superscripted alphabets in the same row differs significantly ( $\mathrm{P} \mathrm{d} " 0.05)$ from each other.

Stretchability: Stretchability is a key feature of Mozzarella cheese. It has ability to produce fibrous strands in hot condition and elongate without breaking when subjected to stress (Guinee et al. 2000). Stretchability of Mozzarella cheese analogue was significantly $(\mathrm{P}<0.05)$ lower than that of natural cheese. Lower stretchability of Mozzarella cheese analogue could be ascribed to type of emulsifying salt used, casein/calcium ratio and the extent of rehydration of casein powder used in preparation of analogue. The functionality of casein could not be as high as that in case of natural cheese where casein is properly hydrated. Again, the stretchability depends upon number of interactions between casein molecules. Stretch requires an intact, interconnected casein network and it is the result of casein-casein interactions that are broken easily but also readily reform at different locations in the casein network (Johnson, 2000).

\section{Sensory evaluation of analogue and natural Mozzarella cheese as pizza topping}

Mozzarella cheese has been characterized by typical acidic creamy flavour, cohesive body as well as fibrous and elastic texture. Mozzarella cheese attains requisite functionality upon refrigerated storage of one week (Fox et al. 2000). Hence, the experimental cheese samples were subjected to baking trials after one week of refrigerated storage. Appearance, flavour, melting, stringiness and chewiness are the parameters evaluated in sensory evaluation (Table 5).

Appearance: Browning, fat leakage and fusion of shreds are observed for appearance. Natural cheese had significantly $(\mathrm{P}<0.05)$ higher appearance score than analogue. Analogue was associated with dull and unattractive appearance with improper fusion of shreds while natural cheese had bright appearance with proper fusion of cheese shreds. The melted cheese had tendency to puff on pizza base when it is taken out from the oven. Natural cheese had shown greater degree of puffing and retained puffing post baking as well. An acid casein based Mozzarella cheese analogue had inferior appearance score compared to natural Mozzarella cheese (Jana and Upadhyay, 2001) while a rennet casein based Mozzarella cheese analogue had appearance score at par with its natural counterpart (Shah et al. 2010).

Flavour: Natural cheese displayed significantly $(\mathrm{P}<0.05)$ higher flavor score than analogue. Natural cheese possessed typical 
Table 5 Sensory scores of analogue and natural Mozzarella cheese judged as pizza topping on 9-point hedonic scale

\begin{tabular}{llll}
\hline Parameters & $\begin{array}{l}\text { Mozzarella Cheese } \\
\text { Analogue }\end{array}$ & $\begin{array}{l}\text { Natural Mozzarella } \\
\text { Cheese }\end{array}$ & CD $(0.05)$ \\
\hline Appearance & $7.08 \pm 0.25^{\mathrm{a}}$ & $7.39 \pm 0.46^{\mathrm{a}}$ & 0.21 \\
Flavour & $6.65 \pm 0.21^{\mathrm{a}}$ & $8.05 \pm 0.29^{\mathrm{b}}$ & 0.29 \\
Melting & $7.12 \pm 0.21^{\mathrm{a}}$ & $7.39 \pm 0.27^{\mathrm{b}}$ & 0.18 \\
Stringiness & $7.10 \pm 0.23^{\mathrm{a}}$ & $7.36 \pm 0.17^{\mathrm{b}}$ & 0.21 \\
Chewiness & $7.17 \pm 0.23^{\mathrm{a}}$ & $6.95 \pm 0.22^{\mathrm{b}}$ & 0.17 \\
Overall acceptability & $7.02 \pm 0.31^{\mathrm{a}}$ & $7.48 \pm 0.23^{\mathrm{b}}$ & 0.27 \\
\hline
\end{tabular}

* Values shown with differing superscripted alphabets in the same row differs significantly (P d" 0.05$)$ from each other.

Table 6 Microbiological quality of analogue and natural Mozzarella cheese

\begin{tabular}{llll}
\hline Parameters & $\begin{array}{l}\text { Mozzarella Cheese } \\
\text { Analogue }\end{array}$ & $\begin{array}{l}\text { Natural Mozzarella } \\
\text { Cheese }\end{array}$ & $\mathrm{CD}(0.05)$ \\
\hline $\mathrm{SPC}, \log _{10} \mathrm{cfu} / \mathrm{g}$ & $3.44 \pm 0.12\left(2.2 \times 10^{3}\right)^{\#}$ & $3.56 \pm 0.10\left(2.5 \times 10^{3}\right)^{\#}$ & $\mathrm{NS}$ \\
Coliform, cfu/g & Absent in $1 \mathrm{~g}$ & Absent in $1 \mathrm{~g}$ & - \\
Yeast \& Mold, cfu/g & $5.00 \pm 0.17$ & $6.00 \pm 0.27$ & $\mathrm{NS}$ \\
\hline
\end{tabular}

\#Figures indicated in parentheses denotes actual SPC (cfu/g) of product

Mozzarella cheese flavor while analogue had slight salty and acidic taste. Analogue was also missing pleasant cheese flavor and also showed vegetable oil like flavor. Natural Mozzarella cheese displayed superior flavor to its analogue (Jana and Upadhyay, 2001). Cheese analogue prepared using the mixture of cow milk and soy milk was found inferior to natural cheese in terms of flavor (Ali et al. 2017). Shah et al. (2010) found similar flavor score for analogue and natural cheese due to use of plastic cream as a fat source.

Melting: Natural cheese had significantly $(\mathrm{P}<0.05)$ higher melting score than analogue. Natural cheese showed uniform melting and proper fusion of cheese shreds while analogue showed incompletely fused cheese shreds which could be attributed to difference in orientation of casein and fat molecules in analogue and natural cheese (Badem and Ucar, 2016).

Stringiness: Stretching is a typical characteristic of Mozzarella cheese. Natural cheese secured significantly $(\mathrm{P}<0.05)$ higher score for stringiness than analogue. Analogue produced very thin and fibrous strands while natural cheese had slightly thicker fibrous strands which were liked by the sensory panelists. The lower stringiness score for analogue could be due to improper rehydration of casein resulting into less cohesiveness. Several researchers observed superior stretch in natural Mozzarella cheese than its analogue (Guinee and O'Callaghan, 1997; Guinee et al. 1999; Fox et al. 2000).

Chewiness: Chewiness is the mouthfeel sensation of laboured chewing due to sustained, elastic resistance from the food (Gulzar et al. 2016). Natural cheese obtained significantly $(\mathrm{P}<0.05)$ higher chewiness score than analogue. Analogue was reported to be rough and extremely chewy which was disliked by judges while natural cheese had moderate chewiness which was appreciated by sensory panellists. Therefore, natural cheese was rated superior by judges.

Overall acceptability: Overall acceptability can be interpreted as the measure of overall quality of the cheese. Natural cheese had significantly $(\mathrm{P}<0.05)$ higher score for overall acceptability than analogue due to attractive shiny appearance with moderate fat leakage, pleasant cheese flavour, uniform melting, better stringiness and less chewiness.

\section{Microbiological analysis of analogue and natural Mozzarella cheese as pizza topping}

Microbiological quality of cheese is one of the important aspects from the perspective of food safety, as it is an exceptional growth medium for a varied range of micro-organisms. Hence, it is significant to notice the microbiological quality of cheese for instance the total viable count. Coliform count is an indication of the hygienic practices followed during and after the cheese manufacture. Yeast and mold count gives an idea about the aerial contamination. Therefore, the experimental cheese samples were analyzed for total viable count, coliform as well as yeast \& mold. There was no significant difference in microbiological count between analogue and natural cheese which is indicative of superior hygienic quality maintained during preparation of Mozzarella cheese and analogue.

O'Malley et al. (2000) reported $3.6 \log _{10}$ cfu/g SPC in RCMCA in 1 week aged cheese stored at $8^{\circ} \mathrm{C}$. Han et al. (2015) reported a total viable count of $5.8 \log _{10} \mathrm{cfu} / \mathrm{g}$ in natural Mozzarella cheese prepared by direct acidification method. Rizvi et al. (1999) reported a coliform count as well as yeast and mold count of $<1 \mathrm{cfu} / \mathrm{g}$ in processed Mozzarella cheese. 


\section{Conclusions}

Natural Mozzarella cheese was found superior to acid casein based Mozzarella cheese analogue in terms of textural, functional and sensory characteristics, even though analogue was formulated to meet natural cheese for proximate composition. Natural cheese was more firm, cohesive, springy, gummy and chewy while less adhesive. Natural cheese also displayed better melt and stretch property as well as slightly more fat leakage. Natural cheese was more acceptable from sensory perspective also. Mozzarella cheese analogue was prepared using acid casein. Acid casein is a dehydrated product and its hydration as well as emulsification of vegetable fat with the help of emulsifying salts could not match the native orientation of milk fat and casein which is found in natural Mozzarella cheese. It resulted in poor functional and textural characteristics of analogue. Moreover, the bland flavor of vegetable fat used in analogue was no match for the pleasant flavor of milk fat present in natural Mozzarella cheese. Therefore, natural Mozzarella cheese was found more suitable as pizza topping over acid casein based Mozzarella cheese analogue.

\section{References}

Ali B, Khan KY, Majeed H, Xu L, Wu F, Tao H, Xu X (2017) Imitation of soymilk-cow's milk mixed enzyme modified cheese: their composition, proteolysis, lipolysis and sensory properties. J Food Sci Technol 54:1273-1285

Arimi JM, Duggan E, O'Sullivan M, Lyng JG, O’Riordan ED (2012) Crispiness of a microwave-expanded imitation cheese: Mechanical, acoustic and sensory evaluation. J Food Eng 108:403-409

Bachmann HP (2001) Cheese analogues: A review. Int. Dairy J 11: 505515

Badem A, Ucar G (2016) Cheese analogues. Res \& Rev: J Food Dairy Technol 4:44-48

Chavhan GB, Kanawjia SK, Khetra Y, Puri R (2015) Effect of potassiumbased emulsifying salts on sensory, textural and functional attributes of low-sodium processed Mozzarella cheese. Dairy Sci Technol 95:265-278

Childs JL, Daubert CR, Stefanski L, Foegeding EA (2007) Factors regulating cheese shreddability. J Dairy Sci 90:2163-2174

Cunha CR, Dias AI, Viotto WH (2010) Microstructure, texture, colour and sensory evaluation of a spreadable processed cheese analogue made with vegetable fat. Food Res Int 43: 723-729

Dang L, Li S, Zhang H, Si Y, Wang Z (2015) Crystallization behavior of palm kernel oil moitired by in-situ Focused Beam Reflectance Measurement (FBRM) and Particles Video Microscope (PVM) during suspension crystallization. Adv Materials Phy Chem 5:3-38

Dave RI, McMahon DJ, Oberg CJ, Broadbent JR (2003) Influence of coagulant level on proteolysis and functionality of Mozzarella cheeses made using direct acidification. J Dairy Sci 86:114-126

Dharaiya CN, Jana A, Aparnathi KD (2019) Functionality of Mozzarella cheese analogues prepared using varying protein sources as influenced by refrigerated storage. J Food Sci Technol 56: 5243-5252

Ennis MP, Mulvihill DM (1999) Compositional characteristics of rennet caseins and hydration characteristics of the caseins in a model system as indicators of performance in Mozzarella cheese analogue manufacture. Food Hydrocol 13:325-337
Fox PF, Guinee TP, Cogan TM, McSweeney PLH (2000) Processed cheese and substitute or imitation cheese products. In J Colilla (Ed.) Fundamentals of Cheese Science (pp. 429-451). Gaithersburg, MD: An Aspen Publication

FSSA (2012) Manual of methods of analysis of foods. Microbiological Testing. Ministry of health and family welfare, Government of India, New Delhi

FSSA (2015) Manual of methods of analysis of foods. Milk and milk products. Ministry of health and family welfare, Government of India, New Delhi

Guinee TP (2002) The functionality of cheese as an ingredient: a review. Aust J Dairy Technol 57:79-90

Guinee TP, Caric M, Kalab M (2004) Pasteurized processed cheese and substitute/imitation cheese products. In PF Fox, PLH McSweeney, TM Cogan, TP Guinee (Eds.) Cheese - Chemistry, Physics and Microbiology, (3 ${ }^{\text {rd }}$ Edn., pp. 349-394). London, UK: Elsevier Academic Press

Guinee TP, Harrington D, Corcoran, Mulholland EO, Mujllins C (2000) The compositional and functional properties of commercial Mozzarella, Cheddar and analogue pizza cheeses. Int J Dairy Technol 53:51-56

Guinee TP, O'Callaghan DJ (1997) The use of a simple empirical method for objective quantification of the stretchability of cheese on cooked pizza pies. J Food Eng 31:147-161

Guinee TP, Auty MAE, Catherine M (1999) Observations on the microstructure and heat-induced changes in the visco-elasticity of commercial cheeses. Aust J Dairy Technol 54: 84-94

Gulzar N, Sameen A, Huma N, Shahid M (2016) Influence of mozzarella and semi-ripened cheddar cheese amalgamations on the chemical composition and textural attributes of processed pizza cheese. Pak J Agri Sci 53:209-216

Han JH, Patel D, Kim JE, Min SC (2015) Microbial inhibition in Mozzarella cheese using rosemary and thyme oils in combination with sodium diacetate. Food Sci Technol 24:75-84

Hennelly PJ, Dunne PG, O'Sullivan M, O'Riordan ED (2005) Increasing the moisture content of imitation cheese: effects on texture, rheology and microstructure. Eur Food Res Technol 220:415-420

Jana AH, Mandal PK (2011) Manufacturing and quality of Mozzarella cheese - a review. Int J Dairy Sci 6:199-226

Jana AH, Tagalpallewar GP (2017) Functional properties of Mozzarella cheese for its end use application. J Food Sci Technol 54:3766-3778

Jana AH, Upadhyay KG (2001) Development of a formulation and process standardization for Mozzarella cheese analogue. Indian J Dairy Sci $54: 1-7$

Johnson M (2000) The melt and stretch of cheese. Dairy Pipeline 12:111

Kindstedt PS, Caric M, Milanovic S (2004) Pasta-filata cheese. In PF Fox, PLH Mc Sweeney, TM Cogan, TP Guinee (Eds.) Cheese - Chemistry, Physics and Microbiology, Vol. 2, $3^{\text {rd }}$ edn. Elsevier Academic Press, London, pp 251-277

Kindstedt PS, Kosikowski FV (1985) Improved complexometric determination of calcium in cheese. J Dairy Sci 68:806-809

Lobato-Calleros C, Vernon-Carter EJ, Guerrero-Legarreta L, Soriano-Santos J, Escalona-Beundia H (1997) Use of fat blends in cheese analogues - Influence on sensory and instrumental textural characteristics. J Texture Stud 28: 619-632

McMahon DJ, Fife R, Oberg CJ (1996) Measuring stretch of Mozzarella cheese. Paper presented at 12th Utah State Biennial Cheese Industry Conference, The United States (www.digitalcommons.usu.edu/cgi/ viewcontent.cgi? article $=1029 \&$ context $=$ wdc_conference)

Mizuno R, Lucey JA (2005) Effects of emulsifying salts on the turbidity and calcium-phosphate-protein interactions in casein micelles. $\mathrm{J}$ Dairy Sci 88:3070-3078 
Monaco RD, Calella S, Masi P (2008) Predicting sensory cohesiveness, hardness and springiness of solid foods from instrumental measurements. J Texture Stud 39:129-149

Noronha N, Cronin DA, O'Riordan ED, O'Sullivan M (2008) Flavouring of imitation cheese with enzyme-modified cheeses: sensory impact and measurement of aroma active short chain fatty acids. Food Chem 106: 905-913

O’ Malley AM, Mulvihill DM, Singh TK (2000) Proteolysis in rennet casein based cheese analogues. Int Dairy J 10:743-753

Park J, Rosenau JR, Peleg M (1984) Comparison of four procedures of cheese meltability evaluation. J Food Sci 49:1158-1170

Patel GC, Vyas SH, Upadhyay KG (1986) Evaluation of Mozzarella cheese made from buffalo milk using direct acidification technique. Indian J Dairy Sci 39:394-403

Rachana CR, Surendranath B (2008) Crystallization of milk fat and its importance in the texture of dairy products - A review. Indian J Dairy Sci 61:408-422
Rizvi SSH, Shukla A, Srikiatden J (1999) Processed Mozzarella cheese. United States Patent US 5925398. Cited from https:// www.google.co.in/patents/US5925398

Rowney M, Roupas P, Hickey MW, Evertt DW (1999) Factors affecting functionality of Mozzarella cheese. Aust J Dairy Technol 54:94102

Sabikhi L, Bhongle PA, Sathish KMH (2015) Farmstead and artisanal cheeses: adding value to milk at farmers' doorstep. Indian J Dairy Sci 68:311-315

Savello PA, Ernstrom CA, Kalab M (1989) Microstructure and meltability of model processed cheese made with rennet and acid casein. J Dairy Sci 72:1-11

Shah R, Jana AH, Aparnathi KD, Prajapati PS (2010) Process standardization for rennet casein based Mozzarella cheese analogue. J Food Sci Technol 47:574-578

Sherkat F, Walker M (2002) Functionality and consumer acceptance of pizza cheese analogue. Aust J Dairy Technol 57:135-140

Steel RGD, Torrie JH (1980) In Principles and Procedure of Statistics-A Biometrical Approach $2^{\text {nd }}$ Edn., pp. 137-167 Columbus, The United States: Mc-Graw Hill 